\title{
Correction to: Temperature dependence of viscoelastic Poisson's ratio of cement mortar
}

\author{
Aishwarya Baranikumar (D) C Christa E. Torrence (D) Zachary Grasley $(\mathbb{D}$
}

Published online: 23 February 2022

(C) The Author(s) 2022

\section{Correction to: Materials and Structures (2021) 54:1-13 https://doi.org/10.1617/s11527-021-01693-y}

The article "Temperature dependence of viscoelastic Poisson's ratio of cement mortar", written by Aishwarya Baranikumar, Christa E. Torrence and Zachary Grasley was originally published Online without Open Access. After publication in volume 54, issue 3, article 101 the author decided to opt for Open Choice and to make the article an Open Access publication. Therefore, the copyright of the article has been changed to (C) The Author(s) 2021 and the article is forthwith distributed under the terms of the Creative Commons Attribution 4.0 International License, which permits use, sharing, adaptation, distribution and reproduction in any medium or format, as long as you give

The original article can be found online at https:// doi.org/10.1617/s11527-021-01693-y.

A. Baranikumar $(\bowtie) \cdot$ Z. Grasley

Zachry Department of Civil and Environmental

Engineering, Texas A\&M University, College Station,

TX 77843-3136, USA

e-mail: aish04@tamu.edu

Z. Grasley

e-mail: zgrasley@tamu.edu

\section{E. Torrence}

Department of Materials Science and Engineering, Texas A\&M University, College Station, TX, USA

e-mail: ctorrence@tamu.edu appropriate credit to the original author(s) and the source, provide a link to the Creative Commons licence, and indicate if changes were made. The images or other third party material in this article are included in the article's Creative Commons licence, unless indicated otherwise in a credit line to the material. If material is not included in the article's Creative Commons licence and your intended use is not permitted by statutory regulation or exceeds the permitted use, you will need to obtain permission directly from the copyright holder. To view a copy of this licence, visit http://creativecommons.org/ licenses/by/4.0.

Open Access This article is licensed under a Creative Commons Attribution 4.0 International License, which permits use, sharing, adaptation, distribution and reproduction in any medium or format, as long as you give appropriate credit to the original author(s) and the source, provide a link to the Creative Commons licence, and indicate if changes were made. The images or other third party material in this article are included in the article's Creative Commons licence, unless indicated otherwise in a credit line to the material. If material is not included in the article's Creative Commons licence and your intended use is not permitted by statutory regulation or exceeds the permitted use, you will need to obtain permission directly from the copyright holder. To view a copy of this licence, visit http://creativecommons.org/licenses/by/4.0/.

Publisher's Note Springer Nature remains neutral with regard to jurisdictional claims in published maps and institutional affiliations. 